\title{
Ecosystem Services and Disservices of Vegetation in Recreational Urban Blue-Green Spaces-Some Recommendations for Greenery Shaping
}

\author{
Agata Ćwik ${ }^{1, *}$, Tomasz Wójcik ${ }^{1}$, Maria Ziaja ${ }^{2}{ }^{\oplus}$, Magdalena Wójcik $^{3}$, Katarzyna Kluska ${ }^{3}$ and Idalia Kasprzyk ${ }^{3}$ \\ 1 Department of Nature Conservation and Landscape Ecology, Institute of Agricultural Sciences, Land \\ Management and Environmental Protection, College of Natural Sciences, University of Rzeszów, \\ Ul. Zelwerowicza 4, 35-601 Rzeszów, Poland; tomaszwojcik@ur.edu.pl \\ 2 Institute of Physical Culture Studies, Medical College, University of Rzeszów, Ul. Cicha 2a, \\ 35-326 Rzeszów, Poland; mziaja@ur.edu.pl \\ 3 Department of Biology, Institute of Biology and Biotechnology, College of Natural Sciences, University of \\ Rzeszów, Ul. Zelwerowicza 4, 35-601 Rzeszów, Poland; mwojcik@ur.edu.pl (M.W.); \\ kborycka@ur.edu.pl (K.K.); idalia@ur.edu.pl (I.K.) \\ * Correspondence: acwik@ur.edu.pl
}

\section{check for} updates

Citation: Ćwik, A.; Wójcik, T.; Ziaja, M.; Wójcik, M.; Kluska, K.; Kasprzyk, I. Ecosystem Services and Disservices of Vegetation in Recreational Urban Blue-Green Spaces-Some Recommendations for Greenery Shaping. Forests 2021, 12, 1077. https://doi.org/10.3390/ f12081077

Academic Editor: Francisco J. Escobedo

Received: 30 June 2021

Accepted: 9 August 2021

Published: 12 August 2021

Publisher's Note: MDPI stays neutral with regard to jurisdictional claims in published maps and institutional affiliations.

Copyright: (c) 2021 by the authors. Licensee MDPI, Basel, Switzerland. This article is an open access article distributed under the terms and conditions of the Creative Commons Attribution (CC BY) license (https:// creativecommons.org/licenses/by/ $4.0 /)$.

\begin{abstract}
Urban water bodies are an important asset in terms of climate change. The accompanying vegetation is an integral part of the waterside space system and a source of ecosystem services and disservices. The composition of greenery in waterside spaces should therefore be preceded by detailed research. This research would be the basis for the development of recommendations for enhancement of the positive impact of vegetation on humans and minimisation of its negative effect. The aim of the study was to identify ecosystem services and disservices of vegetation in the four most important waterside recreation spaces in the city of Rzeszów, Poland, and to develop plant composition guidelines. A detailed inventory of vegetation and aerobiological monitoring of the presence of airborne allergenic pollen grains and fungal spores were carried out. Next, the ecosystem services and disservices of the vegetation were determined based on literature data and on our expert judgement. Additionally, a counting of the number of visitors to waterside areas was conducted. All these steps were used to develop recommendations for shaping the vegetation of study areas. The results of the investigations show that the boulevards along the artificial lake function completely differently than other investigated places as the area resembles an urban park, and the water is not the main attraction in this space. The vegetation of the boulevards and the nearby gravel-pit bathing area has mostly a spontaneous character and offers the widest range of ecosystem services and disservices. The management of the vegetation should focus on its health-enhancing values. The vegetation growing near the outdoor swimming pools has been designed by man. Nevertheless, it requires recomposing and is targeted specifically at the enhancement of the visual attractiveness. Additionally, there is a need for planting compact deciduous trees that will provide shade at the multi-media fountain.
\end{abstract}

Keywords: urban waterside space; blue-green infrastructure; urban vegetation; Rzeszów

\section{Introduction}

Blue-green infrastructure (BGI) is one of the most important components of a modern urban system, and the design of this component is still a challenge [1-5]. The relevance of BGI for humans is well-described by the concept of ecosystem services (ES) [4,6], i.e., the benefits of the broad sense of the natural environment [7]. This concept has evolved since the mid-twentieth century and was used for the first time in the 1980s by Ehrlich, Ehrlich, and Mooney [7]. It was developed later by Constanza [8] and Daily [9], who emphasised that ecosystems not only provide certain material goods or perform functions supporting life processes but are also a source of intangible cultural assets. This concept has been 
reorganised into reports [10-12] where ecosystem services are assigned four main roles: provisioning, regulating, supporting, and cultural. The latest CICES classification (Common International Classification of Ecosystem Services) [13] has established three final ES groups that include provisioning, regulating \& maintaining, and cultural roles. Both the urban waterside spaces and the accompanying greenery provide services that can be classified into all these ES groups. Haase [6] uses the terms blue ecosystem services and green ecosystem services. The provisioning (PES) and regulating (RES) services include water supply, alleviation of the urban heat island, mitigation of the adverse climate phenomena, and the interception of pollutants. They also provide habitats for animals and plants, thereby ensuring maintenance of biodiversity [3,6,14-16]. On an urban scale, services related to the local climate are investigated the most frequently [17]. Cultural services (CES) seem to be equally important, especially those that provide people with leisure and recreation $[6,18-20]$. They have a more immaterial facet referring to identity as well as religious, spiritual, and aesthetic experiences, and they create sites of inspiration or heritage [21]. RES and CES are considered the most important aspects for city inhabitants [22]. A special type of these services is provided by urban greenery, which positively influences human health [23]. One of the most noticeable effects of greenery is the improvement of the topoclimate, manifested in reducing temperature and sunlight, providing shade, regulating wind flow, and improving air quality by removing pollutants, thus providing health benefits to people [24,25]. Therefore, urban parks have been extensively investigated and recommendations for their arrangement have been proposed, in particular in terms of the composition of vegetation plantings [26-31]. One of the important recommendations is to avoid planting alien and wind-pollinated species [29,30]. Greenery plays an important role not only in urban parks, but also in waterside areas. It can even determine the attractiveness of relaxation in a waterside area as both vegetation and water form a complex blue-green infrastructure system. The system provides various ecosystem services $[4,6]$, which can be both positive and negative.

One of the negative impacts of vegetation, referred to as disservices (EDS) in the literature [27,32], may include allergenic pollen [27,29,30,32]. Some, such as grass pollen, are highly allergenic and produce huge amounts of pollen throughout the whole of the summer. Fungal spores, mainly Alternaria and Cladosporium, are also considered as one of the most important aeroallergens. They are the most abundant aeroallergen, occurring airborne for a very long time, often simultaneously with Poaceae or Artemisia pollen which increases the risk for allergenic people [29,33]. There are also other threats, e.g., reduced comfort of relaxation in a specific type of vegetation related to, e.g., plants with thorns, spines, stinging hairs, large amounts of fallen leaves in autumn, and the presence of insects or poisonous plant species [34-37]. The potential of these areas for CES can also be reduced by poor water quality [6]. Both ES [38] and EDS should be analysed according to their application, e.g., the formulation of recommendations for the development of waterside spaces [3] based on guidelines developed for urban parks. Therefore, the main aim of the study was to explore the role of vegetation in urban waterside spaces in the development of the ecosystem services of these areas, from the positive and negative aspects related to their recreational function. We endeavoured to achieve this goal through (i) an estimation of the number of visitors to waterside spaces, (ii) identification of the vegetation accompanying waterside spaces and recognition of its ecosystem services and disservices, and (iii) development of recommendations for the management of urban waterside spaces.

\section{Materials and Methods}

\subsection{Study Area}

Four waterside spaces located in Rzeszów, a medium-size European city and the capital of the Podkarpackie Province in South-Eastern Poland (Figure 1), were selected for the analysis. The city is characterised by a continuous increase in population size; it is currently inhabited by 196,600 residents [39]. The type of investments selected by the residents to be 
financed by the city as part of the participatory budget indicates that recreation sites are the most desirable forms of spatial development. This is also confirmed by the high number of visitors to urban parks [28]. Rzeszów lies in a warm temperate climate zone, similar to the entire territory of Poland. Over the last decade, the average annual temperature in the city was $9.7^{\circ} \mathrm{C}$ with an upward trend, and the average precipitation sum slightly exceeded $600 \mathrm{~mm}$ [40]. This creates favourable conditions for vegetation growth, which is also supported by the current increase in the length of the growing season (over 220 days at the end of the 20th century) [41]. July and August are the warmest months, with the same average air temperature of $19.7^{\circ} \mathrm{C}$ calculated for the last decade. In turn, January, with an average temperature of $-1.4{ }^{\circ} \mathrm{C}$, is the coldest month [40]. Simultaneously, the number of hot days with the maximum temperature (Tmax) $\geq 25^{\circ} \mathrm{C}$ and very hot days with Tmax $\geq 30{ }^{\circ} \mathrm{C}$ is gradually increasing [42], with the greatest number of such days in August. In the study year 2019, there were 48 hot and 20 very hot days [40]. Summer is therefore favourable for the use of the blue infrastructure for bathing purposes. The dominant element of the urban water infrastructure is the Wisłok River (Figure 1) with a retention reservoir constructed in the 1970s. Our investigations involved four areas providing waterside recreation spaces to the inhabitants of Rzeszów. They differ in several characteristics: the surroundings-urban tissue and vegetation, as well as the size and role of the water bodies. Each occupies a small area of up to $5 \mathrm{ha}$, which corresponds to small urban parks in the classification proposed by Giedych and Maksymiuk [22]. They include (Figure 1): a complex of urban outdoor swimming pools (S), a multi-media fountain (F), riverside boulevards at the retention reservoir $(\mathrm{R})$, and a post-exploitation reservoir serving as an urban bathing area $(\mathrm{G})$. Except for the Wisłok River and the other areas analysed in the study, there are no other outdoor water bodies in Rzeszów with adequate conditions for recreation and relaxation.

The complex of outdoor municipal swimming pools $(S)$ with an area of 1.6 ha is located in the very centre of the city. The three pools are accompanied by attractive infrastructure, a water playground, and a large lawn shaded by trees. In 2019, before the COVID-19 pandemic, nearly 110,000 visitors to the swimming pool complex were recorded [43]. The area is characterised by poorly diversified vegetation with a few jasmine bushes and an alley of conifer trees. Lawns are the dominant element of vegetation. It is a natural extension of a very popular downtown park [28] characterised by high plant diversity [30].

The multi-media fountain (F, Figure 2 ) is located on a 0.6 ha square. The most important elements in this space are seven electronically controlled fountains [44]. Area F has the most attractive location of all the waterside spaces, i.e., being in the very centre, near the historic castle complex. The site is situated among designed greenery. It includes plantings of ornamental shrubs with large and impressive inflorescences and evergreen shrubs forming low compact carpets. The upper part of the amphitheatre is surrounded by an alley of chestnut and lime. In the close vicinity of the fountain, there are multi-coloured flowerbeds.

The recreation zone at the Rzeszów Reservoir (R) has a completely different character. It is a wide strip of lawns with pedestrian and cycling lanes, bordering the only urban nature reserve "Lisia Góra" (Figures 1 and 2) which has protected old-growth oaks [45]. The site covers an area of 3 ha. It comprises two attractive children's playgrounds, a barbecue shelter, a mini-golf course, and a cafe. There are also benches and sun beds along the pedestrian paths and a picnic/bonfire area. The vegetation in this area and its surroundings has the character of spontaneous greenery, and its most valuable elements are the old-growth oaks in the forest reserve, which represent the Carpinion betuli alliance. The floodplain of the Wisłok River is covered by Alno-Ulmion riparian forests [45]. The vegetation in this area is exposed to strong anthropopressure. In turn, rushes and small groups of willow shrubs cover the recreation area adjacent to the reservoir [46]. 


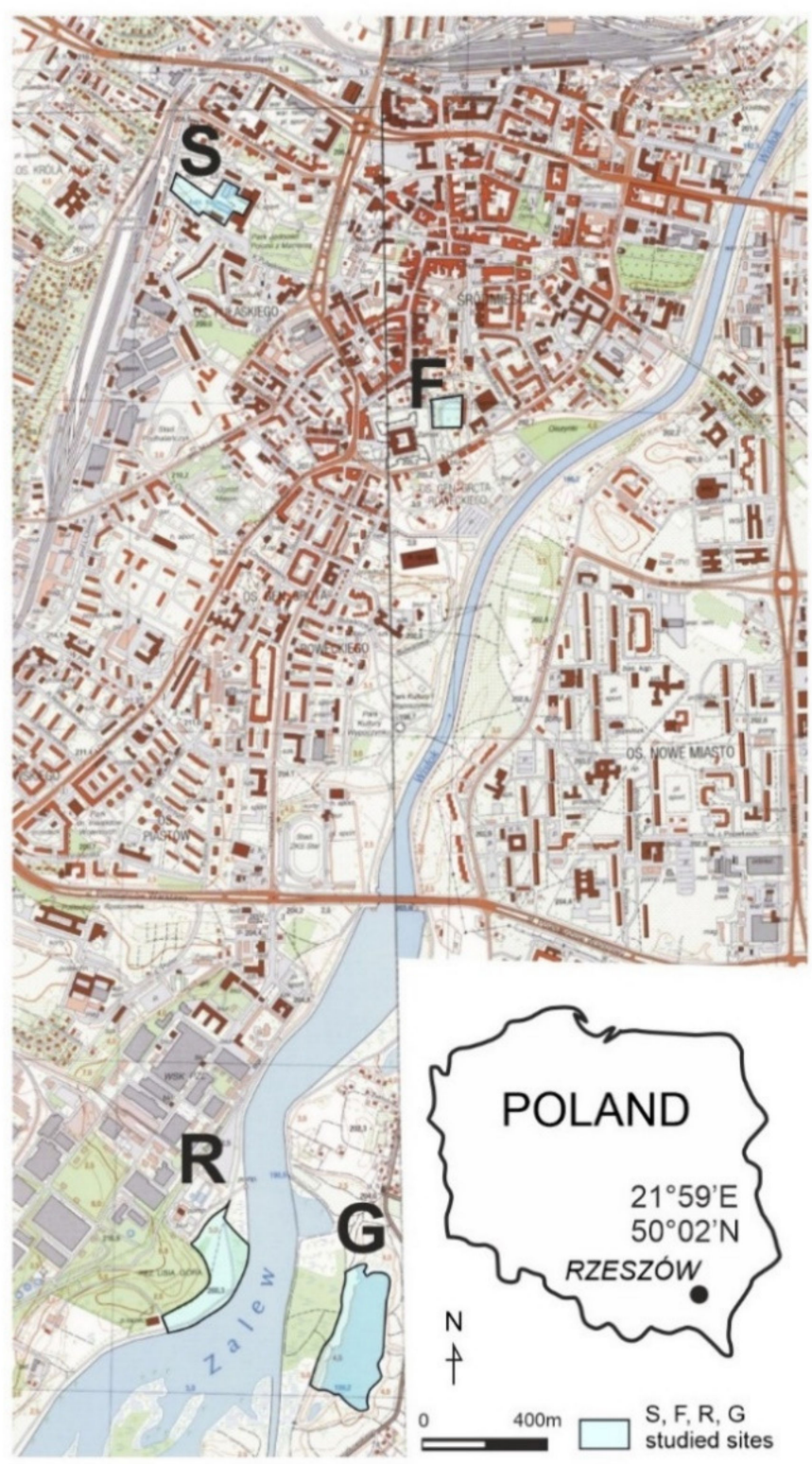

Figure 1. Study area: S—open swimming pools, F-multi-media fountain, R-reservoir, G-gravel pit lake (base map: Topographic map 1:10,000).

The last element of BGI selected for the analysis is the urban bathing area "Żwirownia" (G) located on the Wisłok River floodplain. It is a post-excavation water flooded gravel pit with a sandy beach (Figures 1 and 2). The beach and the pedestrian paths occupy a very small area of $0.6 \mathrm{ha}$, but the surface area of the site including the water reservoir slightly exceeds 5 ha. It has been used as an urban summertime bathing place since 2003 with ca. 10,000 ticketed entries per year [43]. The area is surrounded by spontaneous vegetation-in particular, plants associated with the wet habitats of riparian forests [46]. Nowadays, the urban bathing area surroundings are exposed to strong investment pressure associated with the construction of multi-family housing estates.

\subsection{Assessment of Number of Recreators in Blue-Green Spaces}

The assessment of the use of the waterside spaces by visitors was carried out from $16: 30 \mathrm{~h}$ to $17: 30 \mathrm{~h}$ on 10 days of the bathing season in 2019. Observations were divided into weekdays and weekends, as well as holiday season days (August) and non-holiday season days (June and September). In each of these categories, the studies covered at least 
two different days. The preliminary criteria for selection of the days were the weather conditions that promoted bathing: very hot days $(15.06,16.06,25.06,26.06,10.08,12.08$, 19.08 and 1.09) or hot days (11.08 and 5.09), and the absence of rainfall. The study consisted of an observation of several minutes of the area (scan) to count the visitors within the site boundary at a given time point, divided into those staying there for a longer time and passers-by. The methodology for estimation of the presence of visitors followed the approach described by Adinolfi et al. [26] and Ćwik et al. [28].
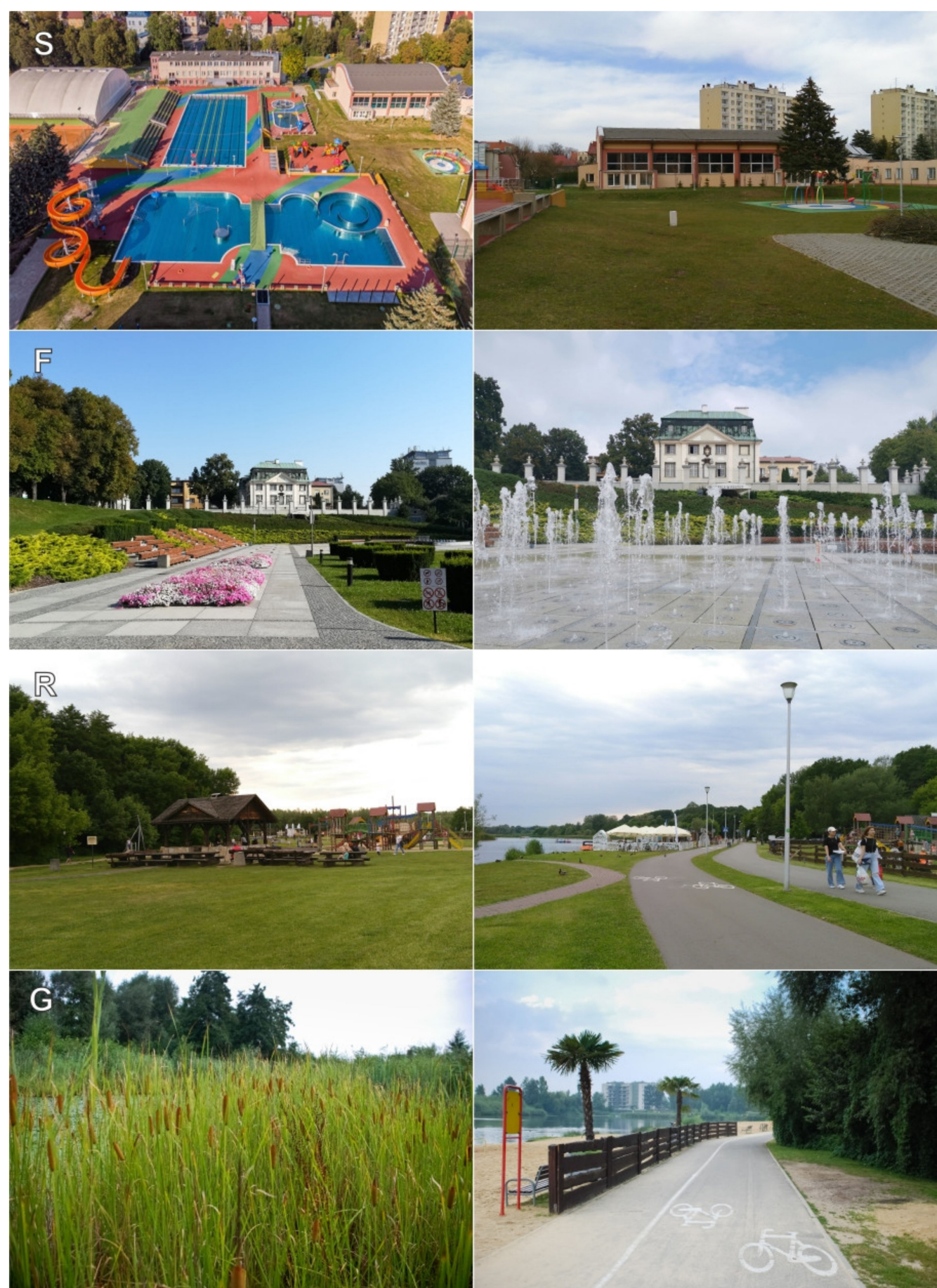

Figure 2. Sites of the study: S-open swimming pools, F-multi-media fountain, $\mathrm{R}-$ reservoir, G—gravel pit lake (photo. S left-T. Poźniak, S right, R—A. Ćwik; F, G-T. Wójcik). 


\subsection{Diagnosis of Vegetation Services and Disservices}

The ecosystem services and disservices of the vegetation were determined based on literature data (see References) and on our expert judgment regarding flora, vegetation and arrangement of the study sites. Both ES and EDS resulted from the diverse characteristics of a given plant species, e.g., an interesting shape of the crown, whether it is poisonous, whether it produces allergenic pollen grains, and the structure of the plant composition, e.g., lack of shade on lawns.

\subsubsection{Analysis of Vegetation}

The floristic studies in the analysed sites were carried out in 2019. They also covered nearby compact vegetation complexes that may affect the ES and EDS of the waterside spaces, but only those growing no farther than $500 \mathrm{~m}$ from the studied site. On the basis of this survey, the floristic list was prepared (Table S1). The next step was to determine the plant species frequency. An inventory was made in 10 randomly selected $10 \times 10 \mathrm{~m}$ plots. For each, the percentage covered with plant species was determined at $5 \%$ intervals. Dominant species were considered as those with average coverage from 10 patches exceeding $5 \%$. Based on the floristic list, the species were classified in terms of origin [47]; ecological groups-forest and shrub, meadow and grassland, water and marsh, anthropogenic, cultivated species [48] (own observations); pollination type-anemogamy, zoogamy, selfing, and cleistogamy [49]; dispersal strategies-anemochory and autochory, anemochory and hydrochory, autochory, autochory and zoochory, autochory and hydrochory, and hydrochory [50]. The description of the species was supplemented with the definition of their ES (edible, melliferous, healing, protected) and EDS (allergenic, poisonous, hallucinogenic, causing bodily injuries) [30,51-54]. Both ES and EDS represented the cultural, provisioning, and regulating groups. The nomenclature of vascular plants followed that proposed by Mirek et al. [55] and Snowarski [56].

\subsubsection{Assessment of the Allergenic Risk of Vegetation}

Aerobiological monitoring was carried out to investigate an essential aspect of the vegetation EDS, i.e., the allergenic plant pollen and fungal spores. The research was conducted in June, August, and September 2019 on the days of counting the visitors (see Section 2.2). During those months, in a temperate climate, most wind-pollinated herbaceous plants pollinate and their pollen dominates in the air [29,57]. It is also the period when airborne allergenic fungal spores occur in high concentrations [33]. This determines the qualitative spectrum of airborne sporomorphs. Ten air samples were collected in each of the four sites. Sampling was performed at a height of approx. $1 \mathrm{~m}$ a.g.l. using a portable Burkard Personal Sampler (Burkard Manufacturing Co Ltd., Rickmansworth, England) for $20 \mathrm{~min}$. The sampler takes in $10 \mathrm{~L}$ of air per minute directly onto a microscopic slide covered with a sticky medium. The pollen grains and fungal spores were counted from a $14 \mathrm{~mm}^{2}$ area of the microscopic slide. An optical microscope was used at magnifications of 400 (pollen grains) or 600 (fungal spores). The results were expressed as the concentration of pollen grains/fungal spores per $1 \mathrm{~m}^{3}$.

\section{Results and Discussion}

There is a clear duality in the differentiation of ES and EDS of the examined sites. Sites $\mathrm{S}$ and $\mathrm{F}$, which are well described by the arranged greenery category, mainly provide services in the form of benefits offered by the aesthetic composition of the greenery or shading in the relaxation infrastructure. In turn, the role of vegetation in sites R and G is mainly associated with the substantial proportion of spontaneous vegetation, which strengthens both ES and EDS. The role of arranged and non-arranged greenery also varies in terms of the visitor load in the individual areas. 


\subsection{Users of Water Spaces}

The complex of outdoor swimming pools (S) is periodically the most popular site of all the analysed water spaces. In the small fenced area (1.6 ha), there were, on average, over 1500 visitors at the same time. The city residents most often visit this attraction on very hot non-working days in June rather than during the holiday season. The average number of swimming pool users was approx. 2500 in a short time interval (Figure 3), which indicates a substantially higher number of visitors per day.

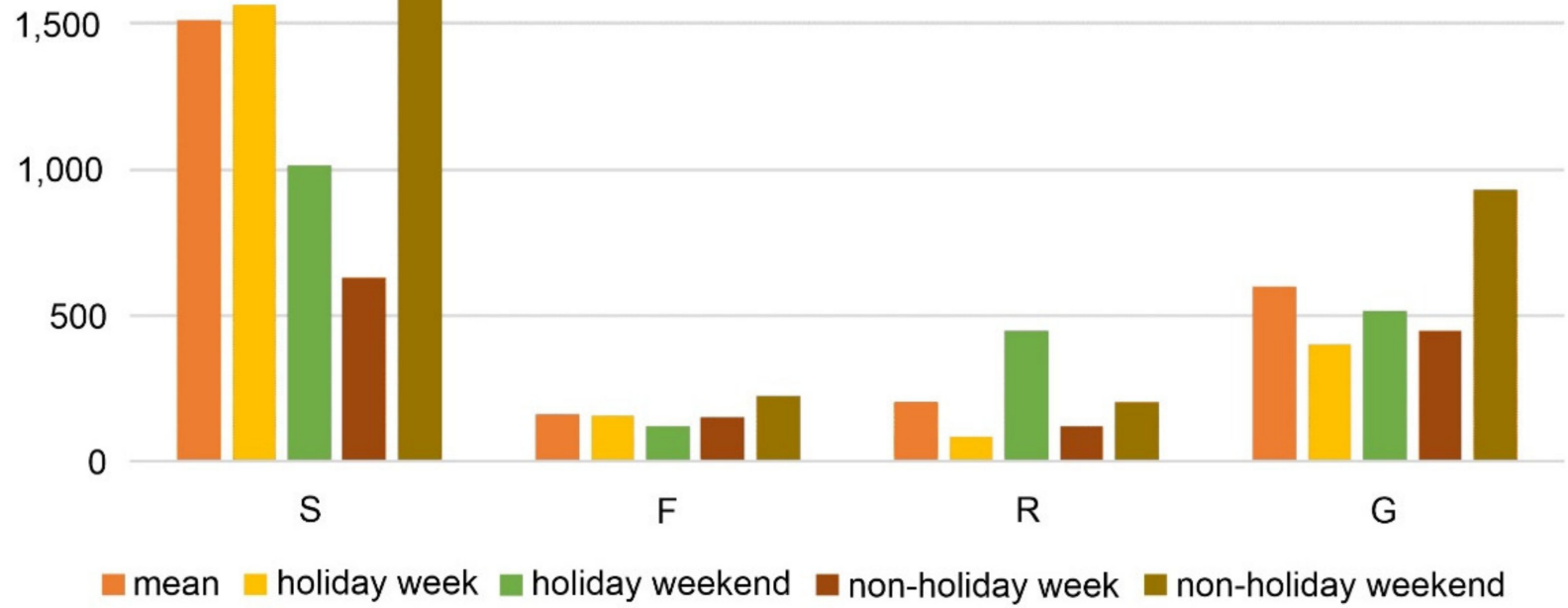

Figure 3. Number of visitors to the study sites in one short period (S-open swimming pools, F-multi-media fountain, $\mathrm{R}$-reservoir, G-gravel pit lake).

On an annual scale, this facility is visited by more than half of the city's population. Almost 110,000 entries were recorded in 2019. When the COVID-19 pandemic restrictions were in force in 2020, the swimming pools were visited by over 56,000 people (Table 1 ).

Table 1. Number of ticketed entries to the municipal bathing areas [43].

\begin{tabular}{cccc}
\hline Year & $\mathbf{2 0 1 8}$ & $\mathbf{2 0 1 9}$ & $\mathbf{2 0 2 0}$ \\
\hline S(Open Swimming Pools) & 97,417 & 109,115 & 56,534 \\
\hline G(Gravel Pit Lake) & 7463 & 9632 & 11,693 \\
\hline
\end{tabular}

Considerable numbers of visitors are recorded in the other bathing area, "Żwirownia" (G). The number of ticketed entries (Table 1) does not fully reflect the scale of the visits to this space, as tickets are only sold periodically and not all day. The present study has shown that visitors come here for waterside relaxation on weekends in the non-holiday season, as in the case of the municipal swimming pools. An equal number of visitors resting in this space at the same time, i.e., approximately 500 , were recorded in the other analysed periods. The largest number of visitors recorded at the same time point exceeded 1100 (16 June 2019). It can be assumed that on that day, site G was probably visited by 
several thousand people. Some visitors regard the bathing area as an alternative in the event of an inability to go to the swimming pools (site S). This was evident on the day the swimming pool had a break-down, when there were almost 1000 visitors to the site at one time vs. only 255 recorded the day before. Similarly, when the pool entries were limited due to the 2020 pandemic, increased sales of tickets were recorded in site G (Table 1).

In terms of the recreational function, the riverside boulevards near the water reservoir (R) have a completely different character. The present study has shown that visitors choose this area to relax mainly during summertime weekends (Figure 3). However, the observations of the number of visitors to this space carried out for over a decade indicate that there can be over 700 visitors to this area in milder weather [58]. A vast majority of this number are playground and cycling path users. The greatest visitor load is recorded during the school year on moderately hot days. As many as 695 visitors were recorded in this area in the control study carried out on Sunday 2 June 2019, at a temperature of $25{ }^{\circ} \mathrm{C}$. These results strongly correspond with the load in another part of the boulevard constituting the city riverside park, where over 720 visitors were recorded on the same day of the school year [28]. The water in site $\mathrm{R}$ is not the main attractor. This role is played by the "Lisia Góra" reserve adjacent to the boulevards and the very attractive infrastructure. The ES functions of the vegetation occurring here may contribute to the intensive sport and recreational use of the riverside boulevards.

Water is definitely the main factor attracting visitors on hot and very hot days in site F. On average, 160 visitors were recorded (Figure 3 ) in this very small area ( 0.6 ha), with over $10 \%$ being passers-by. The time of the observations allowed distinguishing those who visited the place for relaxation. A large group constituted families with children, who were mainly attracted by the direct contact with water impressively supplied by the fountain. Equally important were the aesthetic assets of the site (Figure 2), including the attractive composition of greenery and places to sit. The flat surface of the fountains serves as a water playground. As in sites $S$ and $G$, the largest numbers of visitors were recorded at weekends during the non-holiday period. The lowest visitor load in the fountain site noted during holiday weekends may indicate that the city residents prefer to relax outside the dense urban tissue in summer. This type of water facility attracts visitors with multimedia shows rather than the mere presence of water, although the latter factor should not be underestimated. In a control study carried out at 21:30 h on Saturday 15 June 2019, 988 visitors were recorded at the main show, with $90 \%$ staying in the area for a longer time.

It seems that the increasing number of users of various types of waterside areas is associated with the increasing number of hot and very hot days, which are especially burdensome in cities and reduce the quality of life of their residents. Therefore, there is a growing need for relaxation by the water (urban bathing) or at least contact with water bodies (water playgrounds, fountains) to stay cool [59], which brings a sense of well-being. Faced with the COVID-19 pandemic restrictions in 2020, those who had even visual contact with nature did not report symptoms of depression or anger [60]. As shown by Nutsford et al. [61], contact with water has a better effect on well-being than contact with greenery. The sound and splash of water has a soothing effect, and even a very small water body can be an attractor. In cities, there are usually fewer blue infrastructure elements; hence, it is extremely important to take measures to improve their quality, especially in bathing areas and outdoor swimming pools. Such activities are an important component of the policy of large European cities, such as Paris or Amsterdam [59].

\subsection{Services and Disservices of Vegetation in Waterside Spaces}

The vegetation accompanying the analysed waterside spaces exhibits numerous ES, including cultural ones. Over half of the species from the floristic list $(n=216)$ have such properties (Table S1). As many as half of the species in this group are edible and more than half are used in medicine. Many species represent both these ES forms. All plants contribute to biodiversity-related experience, especially the 108 melliferous species. The floristic list comprises 156 species representing at least one EDS from six categories. Almost 
a $1 / 3$ of the species are allergenic or probably allergenic, and slightly fewer species are toxic. Species of the genus Juniperus have as many as three traits contributing to their adverse or harmful effect on humans: they are allergenic, prickly, and toxic (Table S1). Another species with allergenic properties, i.e., Lolium perenne, is present in almost all four sites (Table 2).

The summary of data in Table S1 and Table 2 does not fully reflect the diversity of the flora and vegetation in the individual urban waterside areas and only partially shows their ES. There is always some negative impact of vegetation on humans; nevertheless, its positive influence prevails (Table 3). This is confirmed by the fact that rich vegetation is a desirable element of riverside urban spaces, which is worth protection, thoughtful arrangement, care, and management $[26,30,31]$.

Table 2. Number and dominant species in the study sites.

\begin{tabular}{|c|c|c|c|c|}
\hline Site & $S$ & $\mathbf{F}$ & $\mathbf{R}$ & G \\
\hline Number of Species & 90 & 138 & 343 & 259 \\
\hline Dominant Species & $\begin{array}{l}\text { Lolium perenne * } \\
\text { Betula pendula } \\
\text { Corylus avellana } \\
\text { Fraxinus excelsior } \\
\text { Flechoma hederacea } \\
\text { Glec } \\
\text { Philadelphus coronarius } \\
\text { Tilia cordata }\end{array}$ & $\begin{array}{c}\text { Lolium perenne }^{*} \\
\text { Acer platanoides } \\
\text { Trifolium repens }^{\wedge} \\
\text { Aesculus hippocastanum } \\
\text { Tilia cordata } \\
{ }^{* \wedge}\end{array}$ & $\begin{array}{c}\text { Petasites hybridus } \\
\text { Typha latifolia } \\
\text { Lolium perenne }^{*} \\
\text { Salix alba }\end{array}$ & $\begin{array}{c}\text { Phalaris arundinacea * } \\
\text { Alnus glutinosa * } \\
\text { Phragmites australis * } \\
\text { Salix alba } \\
\text { Salix triandra }\end{array}$ \\
\hline
\end{tabular}

S-open swimming pools, F-multi-media fountain, R-reservoir, G-gravel pit lake; ^ ecosystem services, * ecosystem disservices (based on: $[36,49,51,62,63])$.

Table 3. Main ecosystem services and disservices of the vegetation in the study sites (S-open swimming pools, F-multimedia fountain, $\mathrm{R}$-reservoir, G-gravel pit lake).

\begin{tabular}{|c|c|c|c|}
\hline Site & Vegetation Type & Ecosystem Services & Ecosystem Disservices \\
\hline \multirow{5}{*}{$\mathbf{S}$} & \multirow{5}{*}{$\begin{array}{l}\text { Arranged greenery: } \\
\text { lawns, trees }\end{array}$} & $\begin{array}{l}\text { - Lawns as places to relax, sunbathing and practice } \\
\text { sports }[20,34,64,65]\end{array}$ & $\begin{array}{l}\text { - The vegetation is monotonous and visually } \\
\text { unattractive; frequent mowing of lawns does not } \\
\text { emphasise the biodiversity of herbaceous } \\
\text { plants [34]; }\end{array}$ \\
\hline & & $\begin{array}{l}\text { - Bushes of Philadelphus provide beautiful flowers and } \\
\text { nice smell. }\end{array}$ & - Insufficient shading $[30,34,66]$ \\
\hline & & & - Lawns as a source of allergens $[62,67,68]$; \\
\hline & & & $\begin{array}{l}\text { - Presence of pollen grains of allergenic tree species, } \\
\text { e.g., from the genera Betula, Corylus, Fraxinus and } \\
\text { Platanus in the adjacent park }[28-30,35] ;\end{array}$ \\
\hline & & & $\begin{array}{l}\text { - Presence of nuisance insects such as mosquitoes } \\
\text { and ticks that can transmit diseases }[34,35] \text {. }\end{array}$ \\
\hline \multirow{4}{*}{$\mathbf{F}$} & \multirow{4}{*}{$\begin{array}{l}\text { Arranged greenery: } \\
\text { tree alleys, } \\
\text { flowerbeds, lawns, } \\
\text { ornamental shrubs }\end{array}$} & $\begin{array}{l}\text { - High aesthetic value of arranged greenery (flowerbeds } \\
\text { and trimmed shrubs and trees) }[34,66] ;\end{array}$ & - Coniferous shrubs-unpleasant to the touch [63]; \\
\hline & & $\begin{array}{l}\text { - Plants can be collected for decoration (flowers) or used by } \\
\text { children to play (e.g., fruits and leaves of horse } \\
\text { chestnut in autumn, popping) }[34,69] \text {; }\end{array}$ & - Lawns as a source of allergens $[29,30,35]$; \\
\hline & & - Possibility of observation of insect pollinators [70]; & - Insufficient shading $[30,66]$. \\
\hline & & $\begin{array}{l}\text { - Scientific and educational values-possibility of } \\
\text { observation of alien species with an interesting habit } \\
\text { (Juniperus } \times \text { pfitzeriana, J. horizontalis, J. sabina, Physocarpus } \\
\text { opulifolius) and attractive flowers (Viburnum lantana, Spiraea } \\
\text { japonica, Potentilla fruticosa) }[34,36,63,69] \text {. }\end{array}$ & \\
\hline
\end{tabular}


Table 3. Cont.

\begin{tabular}{|c|c|c|c|}
\hline Site & Vegetation Type & Ecosystem Services & Ecosystem Disservices \\
\hline \multirow{12}{*}{$\mathbf{R}$} & \multirow{12}{*}{$\begin{array}{l}\text { Arranged greenery: } \\
\text { lawns; } \\
\text { Non-arranged } \\
\text { greenery: rushes, } \\
\text { riparian forests, } \\
\text { oak-hornbeam } \\
\text { forests, willow } \\
\text { thickets }\end{array}$} & $\begin{array}{l}\text { - Vegetation and animals as a source of biodiversity-related } \\
\text { experience [69]; }\end{array}$ & $\begin{array}{l}\text { - Presence of allergenic fungal spores and } \\
\text { allergenic pollen of grasses, trees, and shrubs (e.g., } \\
\text { Populus, Alnus, Corylus, Salix) [27,29,30,35,37,62]; }\end{array}$ \\
\hline & & $\begin{array}{l}\text { - Plants can be collected for decoration, consumption, or } \\
\text { medicinal purposes }[51,69]\end{array}$ & $\begin{array}{l}\text { - Presence of poisonous, psychoactive, and } \\
\text { nuisance plants (prickly, sticky) }[37,51,63]\end{array}$ \\
\hline & & $\begin{array}{l}\text { - Large floristic richness, including numerous melliferous } \\
\text { plants visited by different pollinators (educational values, } \\
\text { observations of pollinator species) }[34,69,70]\end{array}$ & $\begin{array}{l}\text { - Presence of nuisance insects such as mosquitoes } \\
\text { and ticks that can transmit diseases }[34,35]\end{array}$ \\
\hline & & $\begin{array}{l}\text { - Habitat for aquatic, grassland, and forest animal species, } \\
\text { especially birds, including protected species (educational } \\
\text { values, possibility of observation, photography) }[34,69]\end{array}$ & $\begin{array}{l}\text { - Difficulty in practicing water sports posed by } \\
\text { rush vegetation [35]; } \\
\text { - Oak-hornbeam forest creating unfavourable } \\
\text { conditions for hypertension patients [71]. }\end{array}$ \\
\hline & & $\begin{array}{l}\text { - High visual attractiveness of the landscape determined by } \\
\text { the vicinity of various plant formations; }\end{array}$ & $\begin{array}{l}\text { - Higher probability of increased concentrations of } \\
\text { BVOCs (biogenic volatile compounds), resulting } \\
\text { from the presence of dense forest ecosystems [72]; }\end{array}$ \\
\hline & & $\begin{array}{l}\text { - Visual attractiveness of vegetation, e.g., robust trees } \\
\text { (monumental oaks), rush species with large inflorescences } \\
\text { (e.g., Typha latifolia and T. angustifolia) [69]; }\end{array}$ & $\begin{array}{l}\text { - Dense vegetation reducing the sense of } \\
\text { security }[34,35,73]\end{array}$ \\
\hline & & $\begin{array}{l}\text { - Scientific and educational values-possibility of } \\
\text { observation of various terrestrial and aquatic ecosystems, } \\
\text { as well as protected and rare species (e.g., Trapa natans) [69]; }\end{array}$ & \\
\hline & & $\begin{array}{l}\text { - Possibility to relax and practice various forms of } \\
\text { recreation }[20,34,64,65]\end{array}$ & \\
\hline & & $\begin{array}{l}\text { - Aquatic and rush vegetation provides a favourable } \\
\text { habitat for fish (possibility of fishing); }\end{array}$ & \\
\hline & & - Children's playground built of dead logs; & \\
\hline & & $\begin{array}{l}\text { - Health-enhancing effect of oak-hornbeam forest on } \\
\text { humans (anti-tuberculosis effect, increasing immunity, } \\
\text { improving well-being) [71]; }\end{array}$ & \\
\hline & & $\begin{array}{l}\text { - The presence of forest vegetation reduces air pollution } \\
\text { and improves the overall air quality, alleviates the urban } \\
\text { heat island effect, and reduces noise levels, thereby } \\
\text { exerting a positive effect on human health and } \\
\text { well-being }[14-16,74] \text {. }\end{array}$ & \\
\hline \multirow{8}{*}{ G } & \multirow{8}{*}{$\begin{array}{l}\text { Arranged greenery: } \\
\text { lawns; } \\
\text { Non-arranged } \\
\text { greenery: rushes, } \\
\text { trees, and riparian } \\
\text { thickets }\end{array}$} & $\begin{array}{l}\text { - Vegetation and animals may be a source of } \\
\text { biodiversity-related experience }[69,70]\end{array}$ & $\begin{array}{l}\text { - Presence of allergenic fungal spores and } \\
\text { allergenic pollen of grasses, trees, and shrubs (e.g., } \\
\text { Populus, Alnus, Corylus, Salix) [29,30,35,41,75]; }\end{array}$ \\
\hline & & $\begin{array}{l}\text { - Plants can be collected for decoration (e.g., branches with } \\
\text { willow catkins), consumption, or medicinal } \\
\text { purposes }[51,69]\end{array}$ & $\begin{array}{l}\text { - Presence of poisonous, psychoactive, and } \\
\text { nuisance plants (prickly, sticky) }[37,51]\end{array}$ \\
\hline & & $\begin{array}{l}\text { - High floristic richness, including numerous melliferous } \\
\text { plants visited by different pollinators (educational values, } \\
\text { observation of pollinating species) }[69,70] \text {; }\end{array}$ & $\begin{array}{l}\text { - Presence of nuisance insects, including } \\
\text { mosquitoes and ticks that can transmit } \\
\text { diseases }[34,35]\end{array}$ \\
\hline & & $\begin{array}{l}\text { - Habitat for aquatic and wetland animal } \\
\text { species-possibility of observation }[34,69]\end{array}$ & $\begin{array}{l}\text { - The vegetation is dominated by dense and hardly } \\
\text { accessible willow thickets, which reduce the sense } \\
\text { of security }[34,35,73] \text {; }\end{array}$ \\
\hline & & $\begin{array}{l}\text { - Scientific and educational values-possibility of } \\
\text { observation of various terrestrial and aquatic ecosystems } \\
\text { with their species [69]; }\end{array}$ & - No shaded areas on the beach. \\
\hline & & $\begin{array}{l}\text { - Aquatic and rush vegetation provides a favourable } \\
\text { habitat for fish (possibility of fishing); }\end{array}$ & \\
\hline & & $\begin{array}{l}\text { - The presence of forest vegetation reduces air pollution } \\
\text { and improves the overall air quality, alleviates the urban } \\
\text { heat island effect, and reduces noise levels, thereby } \\
\text { exerting a positive effect on human health }[14-16,74] \text {; }\end{array}$ & \\
\hline & & $\begin{array}{l}\text { - Willow and poplar riparian forests increase immunity in } \\
\text { the human organism [71]. }\end{array}$ & \\
\hline
\end{tabular}




\subsubsection{ES and EDS of Vegetation of Outdoor Swimming Pools Area}

The specific manifestations of ES and EDS clearly vary between the analysed sites (Table 3). The outdoor swimming pool zone (S) is characterised by the poorest and least diverse vegetation. In this site and in parks adjacent to the pool area, only 90 species were recorded, with a slight dominance of native species (Figure 4, Table 2 and Table S1). In terms of the ecological groups, cultivated species dominated (half of the species), whereas those from the meadow and grassland as well as the forest and shrub groups were less abundant (Figure 5). The species recorded in this space were predominantly zoogamous and anemogamous (Figures 6 and 7) and were dispersed mainly via anemochory or autochory (Figure 8). The poorly arranged greenery (lawns and solitary trees) offers insufficient ES (Table 3), i.e., mainly space for social activities: resting, sunbathing, games, and sports. There is a substantially greater range of EDS in this area. The poor absence of diverse and attractive vegetation (e.g., deciduous trees with extensive crowns, hedges, ornamental flowerbeds) is largely responsible for the low aesthetic value of this place (Table 3). The shaping of greenery should therefore be aimed at reducing the predominance of conifers, unpleasant to touch, and the planting of attractive shrubs with ornamental flowers. This area is characterised by the highest number of allergenic species in the most frequent species group (Table 2). The lawns surrounding the swimming pools may especially be a source of allergens due to the presence of the strongly allergenic L. perenne of the family Poaceae. The concentration of airborne grass pollen as well as Alternaria spores may pose a threat to sensitised visitors in June and July (Figure 9). Mainly airborne grass pollen is observed in this period, as well as the beginning of recording very high fungal spore concentration of many taxa $[33,57]$. The discomfort associated with the absence of shade around the pools and the insufficient number of trees providing shelter growing only along the fence should be mentioned as well (Table 3). There is therefore a need to lead the vegetation in such a direction as to give shade, which may mean limiting the pruning of already planted young trees.

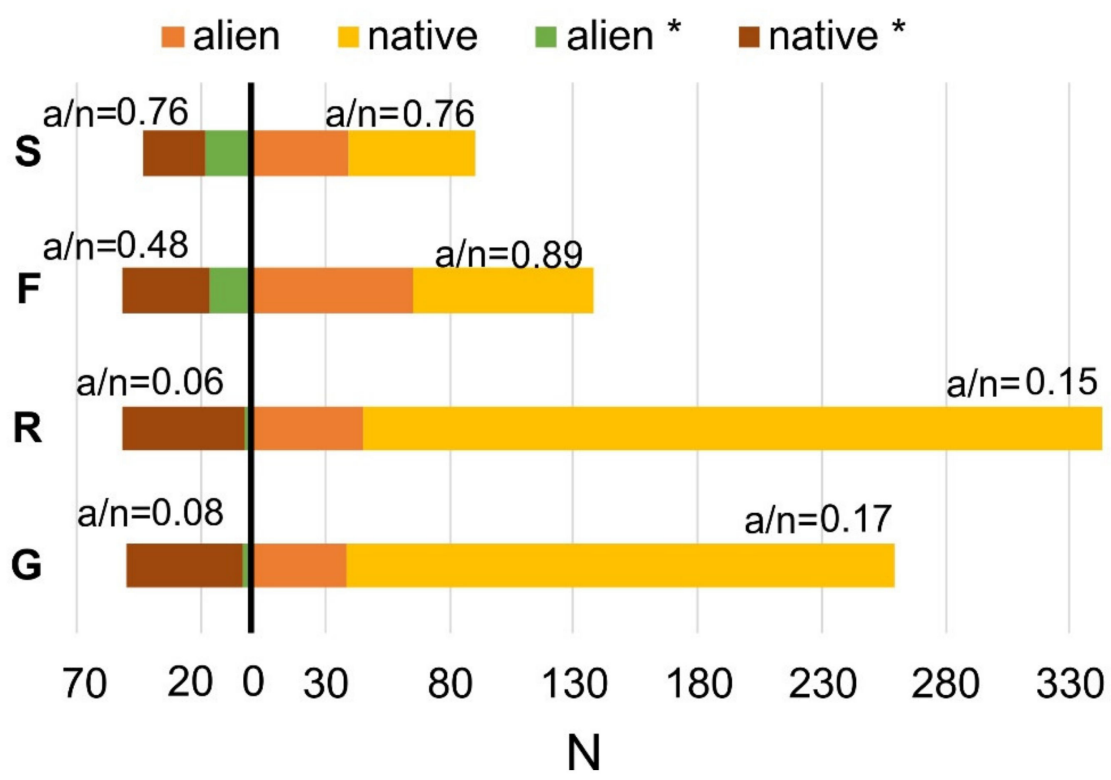

Figure 4. Number $(\mathrm{N})$ of all alien and native species, alien (a) and native (n) species among the frequently occurring species $\left(^{*}\right)$, and the proportion $(\mathrm{a} / \mathrm{n})$ between these two categories of species (S-open swimming pools, F-multi-media fountain, R-reservoir, G-gravel pit lake). 
120

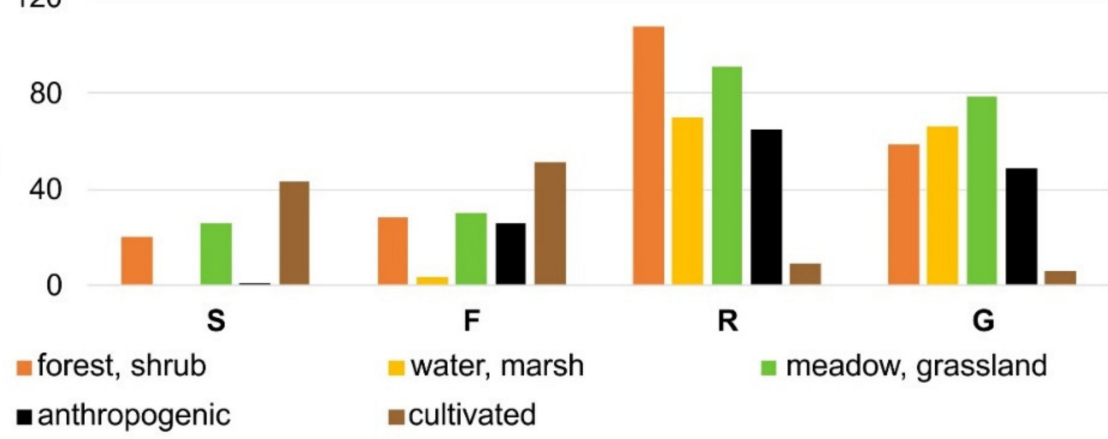

Figure 5. Number of species of different ecological types (S-open swimming pools, F-multi-media fountain, R-reservoir, G-gravel pit lake).

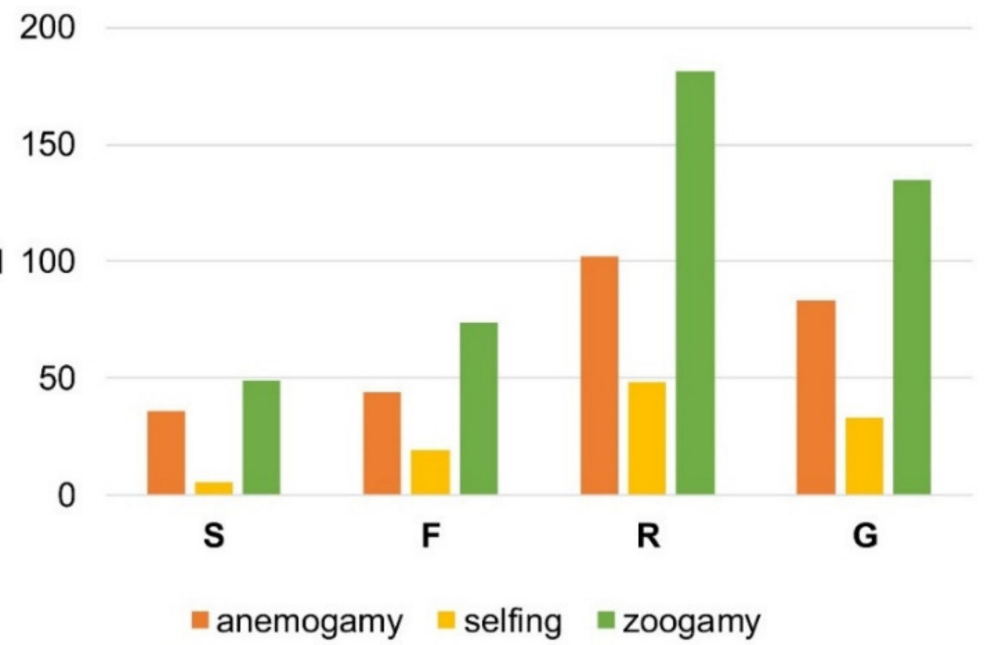

Figure 6. Number of species with the main types of pollination (S-open swimming pools, F-multimedia fountain, R-reservoir, G-gravel pit lake).

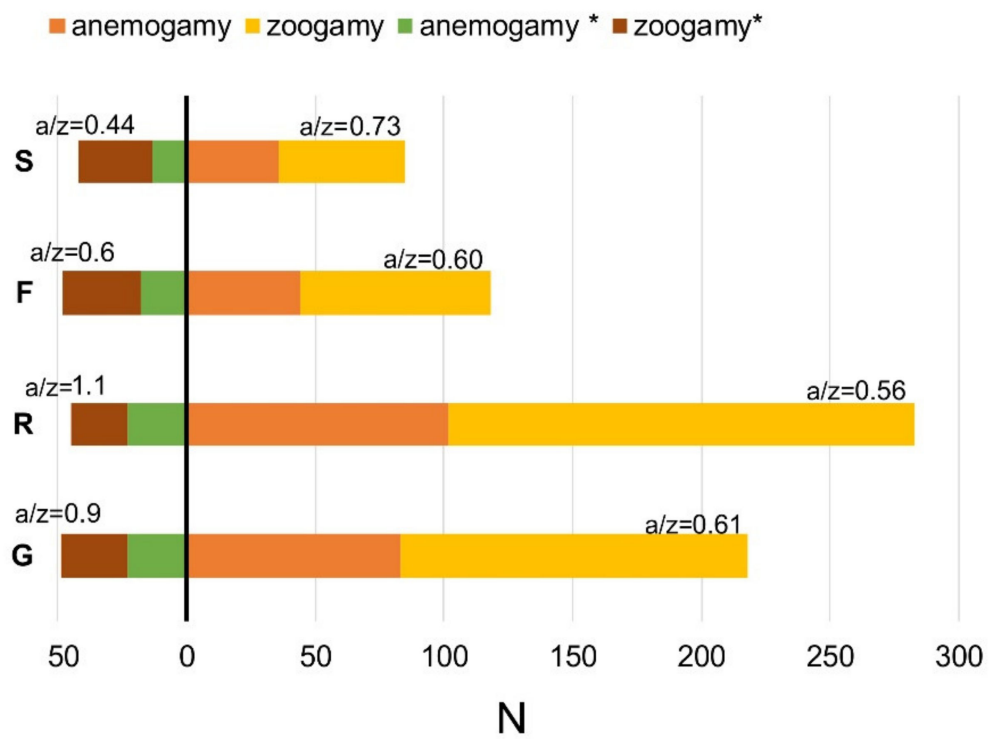

Figure 7. Number of all species pollinated by wind and insects, pollinated by wind and insects among the frequently occurring species $\left({ }^{*}\right)$, and the proportion between these two categories of species (S—open swimming pools, F-multi-media fountain, $\mathrm{R}$-reservoir, $\mathrm{G}$-gravel pit lake). 


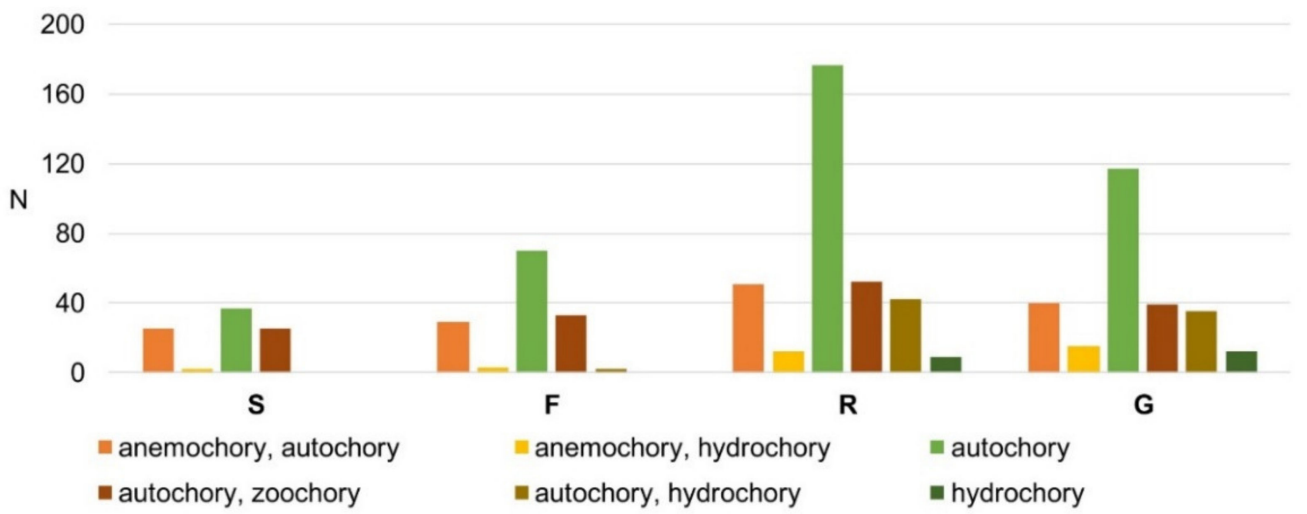

Figure 8. Number of species with different dispersal strategy (S—open swimming pools, $\mathrm{F}$-multi-media fountain, $\mathrm{R}$ reservoir, G-gravel pit lake).

\subsubsection{ES and EDS of Vegetation of Multi-Media Fountain Area}

The multi-media fountain zone $(\mathrm{F})$ comprises arranged greenery with 138 species (in equal parts native and alien species) (Figure 4). This site has the highest number of cultivated species (Figure 5). Autochory is the dominant dispersal strategy (half of the species) (Figure 8), and a majority of the species are zoogamous (Figures 6 and 7). The space is characterised by meticulously designed greenery: tree alleys, trimmed shrubs and trees, flowerbeds, and lawns. This contributes to the high aesthetic value of this place. The species in this zone have an interesting habit and attractive flowers (Table 3), which can be used for educational purposes. Properly arranged urban greenery is highly appreciated by city inhabitants, as reported by Hayden et al. [64], who emphasised that orderly plantings and well-maintained lawns serve as the background for all elements of the urban landscape. Notably, urban ecosystems are often a habitat for both native species and attractive alien plants, which can enhance the aesthetic assets and biodiversity of small greenery islands [65]. Additionally, the diversity of plants, especially flowering species, attracts numerous pollinators (e.g., bees and bumblebees), which is a source of biodiversityrelated experience. The negative impact of vegetation is mainly associated with their role as a source of allergens (L. perenne). Although arranged greenery predominates in this area, high concentrations of airborne Urtica pollen were observed (Figure 9a). This may be a result of the long-distance transport of very small nettle pollen grains from areas dominated by this type of vegetation. This type of transport has been described in the case of other plants, e.g., representatives of the genus Ambrosia [76]. The concentrations of Cladosporium spores were characterised by high variability during the season. Their values recorded from June to mid-August exceeded the threshold allergy-inducing values (Figure 9; Table S2). The presence of coniferous shrubs (juniper species) that are unpleasant to the touch may also be an element of EDS, and this kind of shrub should be limited in space arrangement. The lawns and low shrubs growing in the immediate vicinity of the fountain do not provide shade. This is an essential element of EDS, as staying in full sun in this area can be inconvenient and dangerous to children playing in this space. As shown by Gunawardena and Kershaw [15], vegetation is more important than water in mitigation of the local climate in this type of space, and a dense canopy should be achieved rather than solitary trees to provide shade. Therefore, in the vicinity of the multi-media fountain, there is a need to plant deciduous trees in such a way that they constitute a compact canopy. Certainly, water can contribute to the air-cooling provided by vegetation in some situations. Elements of green and blue infrastructure should therefore be introduced into the urban tissue to provide city residents with the possibility of contact with cooler places where they can be protected from urban heat stress. 
Poaceae

a
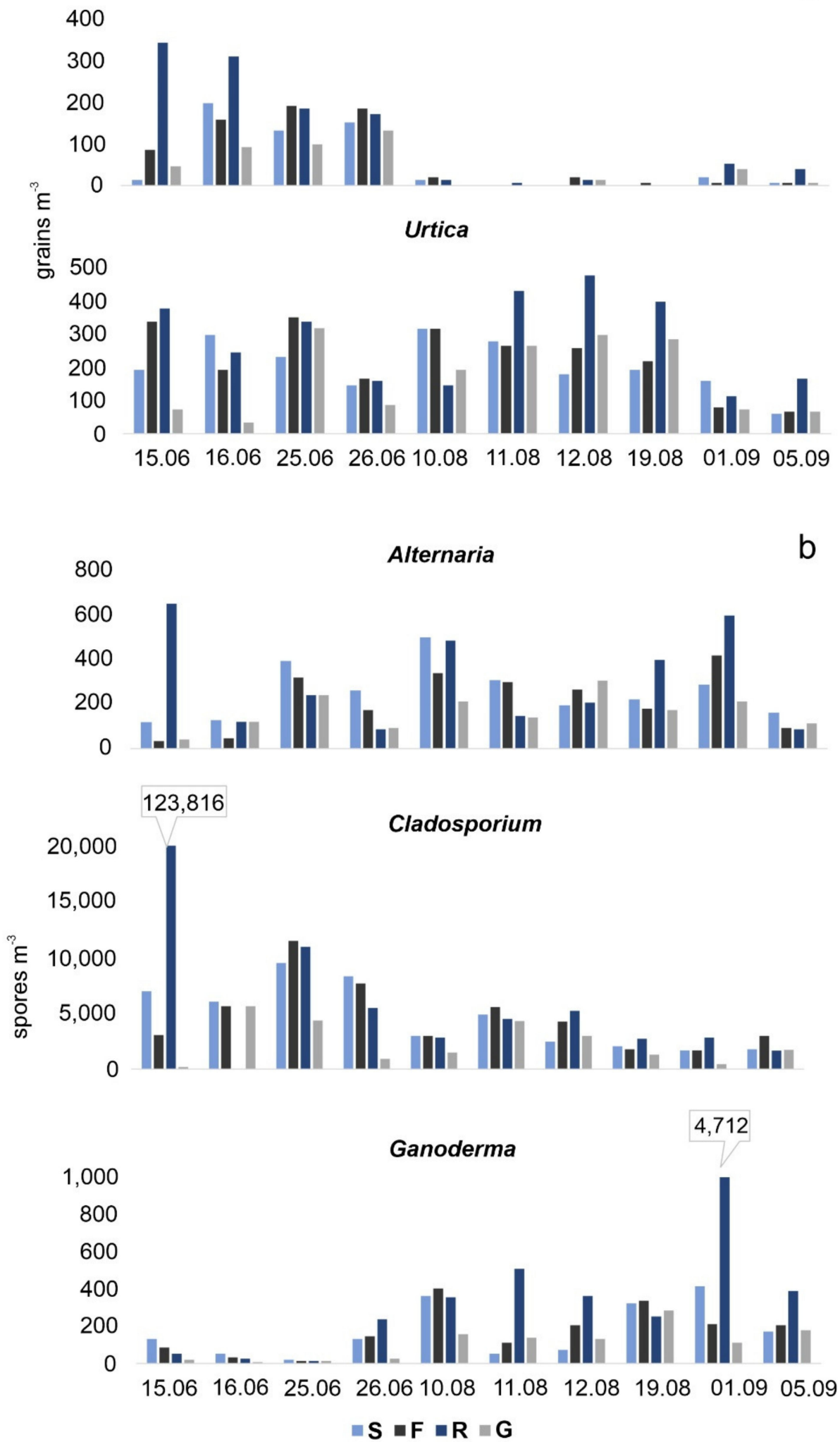

Figure 9. (a) Number of Poaceae and Urtica pollen grains in $1 \mathrm{~m}^{3}$ of the air in the study sites; (b) Number of Alternaria, Cladosporium, and Ganoderma fungal spores in $1 \mathrm{~m}^{3}$ of the air in the study sites (S-open swimming pools, F-multi-media fountain, $\mathrm{R}$-reservoir, G-gravel pit lake). 


\subsubsection{ES and EDS of Vegetation of Riverside Boulevards}

Visitors to site $\mathrm{R}$ had the opportunity to use the diverse ES range associated largely with the vegetation diversity. Along the boulevards and in their immediate vicinity, there are natural forest, scrub, aquatic, and rush ecosystems, as well as arranged lawns (Table 3). The flora of this area represents different ecological groups: forests and shrubs, as well as meadows and grasslands (Figure 5). This space is also characterised by the greatest species richness (343 species, including 298 native species), which encourages naturalists and visitors to explore nature. The area offers a wide range of interesting species of plants pollinated by animals (half of the total; Figure 6) and dispersed by animals (Figure 8), e.g., Cornus spp., Euonymus spp., Prunus spp., Ribes spp., Rubus spp., Rosa spp., and Sambucus spp. (Tables 2 and 3; Table S1). The "Lisia Góra" forest reserve provides a wide range of ES and EDS (Tables 2 and 3). It plays an important scientific and educational role, especially in investigations of forest communities and related ecological processes $[45,58]$. The oak-hornbeam forest also exerts health-enhancing effects [71]: it provides anti-tuberculosis properties, enhances immunity, and improves well-being (Table 3). Furthermore, tree clusters lower the air temperature and increase humidity [15], thereby improving the human comfort index on hot days $[65,74]$. They also reduce air pollution and noise levels and thus have a positive effect on human health [14,16]. Similar to forest habitats, aquatic, rush, and grassland habitats offer educational services. Numerous animal species, e.g., amphibians, birds [77], and various pollinator groups can be observed in the waterside area of the artificial lake. The most interesting plant species with large inflorescences include Butomus umbellatus, Lythrum salicaria, Lysimachia vulgaris, and Typha spp. There are also rare species (Leersia oryzoides) [46] and protected species (Trapa natans). This is the largest locality of the latter species in South-Eastern Poland [78]. Additionally, there is a wide range of melliferous plants, which can be regarded as ES (Table S1). A large area is covered by lawns with a designed recreational space, which is ideal for such interactions between visitors as team games or picnics (Table 3) [20]. The vegetation of site $\mathrm{R}$ also offers a relatively wide range of EDS, with the allergenic effect as the most important disservice. This area was also characterised by the highest concentrations of the strongest allergenic spores, i.e., Alternaria, Cladosporium, Epicoccum, and Ganoderma, especially in late summer (Table S2, Figure 9b). In this space, there were the maximum concentrations of fungal spores that do not pose a threat to humans, or their effects have not been thoroughly investigated to date (Table S2). An important source of allergenic fungal spores is the neighbouring oak-hornbeam forest, which is also a producer of allergenic pollen. Nevertheless, inside the forest, the risk of contact with this type of allergen may be lower than in the directly adjacent open area [75]. On days with favourable conditions for relaxation by the river, i.e., hot and very hot days, a risk is posed by the allergenic pollen of herbaceous plants, e.g., Poaceae, Plantago, and $U$. dioica, growing mainly in the recreation zone (Figure 9a, Table S2). However, it should be emphasised that site $R$ is not loaded by visitors during such days (Figure 3). Management of arranged greenery may cause a sharp increase in the concentration of aeroallergens in the air, which is impossible to predict in pollen messages broadcast in the media. This was the case on 15 June 2019 when the lawns were being mown, and extremely high concentrations of Cladosporium and Alternaria spores, as well as Poaceae pollen grains (Figure 9), i.e., one of the strongest airborne allergens, were recorded $[67,68]$. However, not only herbaceous plant pollen is allergenic. Blades and leaves of grasses contain allergens, whose concentrations increase after mowing [62]. Paradoxically, the presence of oak-hornbeam forests represents EDS for sensitive visitors, which is reflected in a strong stimulatory effect and thus a negative influence on their health [71]. Green areas also pose a threat associated with the presence of nuisance insect parasites (mosquitoes, ticks) and pathogens that are harmful to human health [79]. Compact vegetation may lower the sense of security, although this depends on many social and psychological factors [80]. In turn, spontaneous vegetation appearing in public spaces, e.g., in parks, is positively perceived by their users [65]. The management of the vegetation of site $\mathrm{R}$ should focus on its health-enhancing values; in the 
warm temperate climate zone conditions, this means introducing species characteristic of oak-hornbeam communities and avoiding large compositions of allergenic plants.

\subsubsection{ES and EDS of Vegetation of Municipal Bathing Area}

The urban bathing area $(\mathrm{G})$ is characterised by great floristic richness (Table 2 and Table S1). Native species clearly dominate over alien plants (Figure 4). In terms of ecology, species typical of meadow and grassland as well as water and marsh communities prevail, while cultivated plants represent the lowest proportion (Figure 5). More than half of the plant species are zoogamous or semi-zoogamous (Figures 6 and 7). In terms of dispersal, autochorous species dominate (Figure 8 ). The vegetation surrounding this site has a natural and semi-natural character. It comprises dense willow thickets as well as water and rush vegetation surrounding the water reservoir, where various species-rich ecosystems develop. Melliferous plants attract insects with their shape (I. grandulifera), colour (L. salicaria), or aroma (P. avium). The space offers humans double ES connected with observation of the floral variety and insect visitors [52,54]. The ES are also associated with medicinal and edible species, which can potentially be used by humans, e.g., Armoracia rusticana, Crataegus monogyna, Prunus spinosa, and Stachys palustris (Table S1) [51]. Other interesting plants are rush (Iris pseudacorus, T. latifolia, T. angustifolia, and T. laxmani) and aquatic (Alisma plantago-aquatica, Hydrocharis morsus-ranae, Nuphar lutea, and Polygonum amphibium) species with impressive inflorescences or an interesting habit (Table 3). A positive impact on human immunity may be exerted by willow thickets, with the species composition resembling Salici-Populetum riparian forests [71]. Another manifestation of the ES of rush vegetation is its function as a habitat for water birds, including rare and protected species, which are interesting not only for professional ornithologists. The overgrowing water reservoir can also create a spawning ground for fish, prompting the possibility to catch tench, pike, or roach. Approximately $1 / 3$ of plant species present in site $G$ and its surroundings are associated with various types of EDS (Table S1). The predominant alders in the species composition are a source of allergenic pollen (Table 2). However, with their early flowering date, they do not pose a threat to visitors of the bathing area in summer. Nevertheless, the presence of alder pollen grains in summer is not surprising (Table S2). This is a typical example of a secondary shedding characteristic of pollenproducing plants [81]. The ruderal vegetation growing in this space is also a potent source of allergenic pollen, especially Artemisia, Chenopodium, and Poaceae taxa (Table 2 and Table S2, Figure 9a). The EDS may also be related to the presence of toxic and psychoactive species. Accidental poisoning may be caused after eating, e.g., Chelidonium majus, Saponaria officinalis, Ranunculus sceleratus, or Oenothera aquatica [51]. The compact and barely accessible willow thickets may hamper access to the water table and reduce the sense of security, as in site $\mathrm{R}$ (Table 3). Additionally, the rush vegetation and the accompanying riparian forests are habitats for nuisance insects, e.g., mosquitoes and ticks, which additionally act as vectors of serious diseases [79]. Another manifestation of EDS is the absence of shaded places around the beach that would provide shelter on very hot days. This may be an important drawback, especially for families resting with children. The municipal bathing area therefore requires the introduction of dense plantings at the beach, of native origin, providing shade but not causing aeroallergenic risk. At the same time, they should be species related to the riparian habitat. All these criteria are met, for example, by female willow specimens.

\section{Conclusions}

Climate challenges associated with the increasing air temperature in cities may underline the importance of blue-green infrastructure for quality of life and, in particular, its health-related and recreational functions. Therefore, spatial planning should not allow wasting such city assets as the presence of water bodies. The present study confirms that waterside spaces, e.g., bathing areas or fountains, are a highly desirable element of the urban tissue, as evidenced by the visitor load in such areas. Although water is un- 
doubtedly an attractor in these places, it is impossible to analyse their health-enhancing and recreational role by disregarding the accompanying vegetation. Its role is very well reflected in the concept of ecosystem services, which can be both services and disservices. The former are represented by the health-enhancing values of various plant communities, the creation of shade, visual values, and various educational aspects associated with the observation of flora and fauna. It seems that non-arranged spontaneous greenery serves a larger range of both ES and EDS. Visitors to waterside spaces may not necessarily be aware of the vegetation disservices, mainly the allergenic threat with airborne plant pollen and fungal spores. The responsibility for minimisation of these risks should rest not only with administrators, but also with the designers and planners of such spaces.

Ecosystem services of vegetation with importance for visitors relaxing by the water are especially visible in vegetation that surrounds the waterside directly, i.e., in direct contact with humans. In turn, the negative aspects are related to vegetation growing in the immediate vicinity and plants present within a distance of several hundred metres or even more remote plant complexes that can be a potent source of aeroallergens. The design of waterside greenery should take into account the high dispersal potential of allergenic fungal spores and plant pollen. In such places, species that provide shade over a large area should be planted, e.g., trees with wide crowns (A. hipocastanum), visually interesting aspects (Salix $\times$ sepulcralis - female specimens), or pollinator attractants (Robinia pseudoacacia). Additionally, lawns should be mown before the pollen release period, and planting alien allergenic species such as plane trees is not recommended. An interesting example of a proper composition of greenery is the surroundings of the multi-media fountain; however, the absence of shaded areas is its drawback. In order to mitigate the local climate and increase the comfort and safety of rest in this space, several trees with a compact crown should be planted without interference in the visual assets. In turn, the greenery directly surrounding the most periodically loaded municipal swimming pools requires recomposing. The introduction of visually more attractive vegetation and deciduous trees could enhance the attractiveness of the surroundings of the area and provide space for visitors enjoying full sun (sunbathing) and those preferring shade.

The present study has shown that the function of riverside boulevards resembles a classic urban park, and the area plays a different role than the sites where visitors have direct contact with water. While the bathing places and the multi-media fountain are most needed by the residents on hot and very hot non-working days in the non-holiday season, the riverside boulevards are more frequently visited in fine weather during the holiday period. This may be associated with the better conditions for sport activities provided by the boulevards. If this is the case, the ecosystem services and disservices of their vegetation are important. Therefore, management of greenery should be focused on its health-enhancing values, which may consist in introducing species characteristic of oak-hornbeam communities in the conditions of the temperate climate zone. As in the case of the urban bathing areas, large compositions of allergenic plants should be avoided.

Supplementary Materials: The following materials are available online at https:/ /www.mdpi.com/ article/10.3390/f12081077/s1, Table S1: List of plant species with their characteristics, Table S2: Number of pollen grains and fungal spores in $1 \mathrm{~m}^{3}$ in the study sites.

Author Contributions: Conceptualization, A.Ć. and I.K.; methodology, A.Ć., I.K., T.W. and M.Z.; validation, I.K.; formal analysis, A.Ć., I.K., K.K., M.W., T.W. and M.Z.; investigation, A.Ć., K.K., M.W., T.W. and M.Z.; resources, K.K., M.W., T.W. and M.Z.; data curation, I.K.; writing-original draft preparation, A.Ć., I.K., T.W. and M.Z.; writing-review and editing, A.Ć. and M.W.; visualization, A.Ć., I.K. and M.W.; supervision, I.K. All authors have read and agreed to the published version of the manuscript.

Funding: This research received no external funding.

Conflicts of Interest: The authors declare no conflict of interest. 


\section{References}

1. Alves, A.; Vojinovic, Z.; Kapelan, Z.; Sanchez, A.; Gersonius, B. Exploring trade-offs among the multiple benefits of green-bluegrey infrastructure for urban flood mitigation. Sci. Total. Environ. 2020, 703, 134980. [CrossRef]

2. Bellezoni, R.A.; Meng, F.; He, P.; Seto, K.C. Understanding and conceptualizing how urban green and blue infrastructure affects the food, water, and energy nexus: A synthesis of the literature. J. Clean. Prod. 2021, 289, 125825. [CrossRef]

3. Gehrels, H.; van der Meulen, S.; Schasfoort, F.; Bosch, P.; Brolsma, R.; van Dinther, D.; Geerling, G.; Goossen, M.; Jacobs, C.; de Jong, M.; et al. Designing Green and Blue Infrastructure to Support Healthy Urban Living; TO2 Federatie: Utrecht, The Netherlands, 2016; p. 109.

4. Iojă, C.I.; Badiu, D.L.; Haase, D.; Hossu, A.C.; Niță, M.R. How about water? Urban blue infrastructure management in Romania. Cities 2021, 110, 103084. [CrossRef]

5. Suleiman, L. Blue green infrastructure, from niche to mainstream: Challenges and opportunities for planning in Stockholm. Technol. Forecast. Soc. Chang. 2021, 166, 120528. [CrossRef]

6. Haase, D. Reflections about blue ecosystem services in cities. Sustain. Water Qual. Ecol. 2015, 5, 77-83. [CrossRef]

7. Solon, J.; Roo-Zielinska, E.; Affek, A.; Kowalska, A.; Kruczkowska, B.; Wolski, J.; Degórski, M.; Grabińska, B.; Kołaczkowska, E.; Regulska, E.; et al. Świadczenia Ekosystemowe w Krajobrazie Młodoglacjalnym. Ocena Potencjału i Wykorzystania [Ecosystem Services in a Postglacial Landscape. Assessment of Potential and Utilisation]; IGiPZ PAN, Wydawnictwo Akademickie SEDNO: Warsaw, Poland, 2017; p. 469.

8. Costanza, R.; d'Arge, R.; Groot, R.; Farber, S.; Grasso, M.; Hannon, G.; Limburg, K.; Naeem, S.; O’Neill, R.V.; Paruelo, J.; et al. The value of the world's ecosystem services and natural capital. Nature 1996, 387, 253-260. [CrossRef]

9. Daily, G.C. Nature's Services: Societal Dependence on Natural Ecosystems; Island Press: Washington, DC, USA, $1997 ;$ p. 393.

10. MEA. Millennium Ecosystem Assessment. Ecosystems and Human Well-being: Synthesis; Island Press: Washington, DC, USA, 2005; p. 137.

11. Kumar, P. TEEB: The Economics of Ecosystem and Biodiversity. Ecological and Economic Foundation; Routledge: London, UK, 2010; p. 410.

12. Maes, J.; Teller, A.; Erhard, M.; Liquete, C.; Braat, L.; Berry, P.; Egoh, B.; Puydarrieux, P.; Fiorina, C.; Santos, F.; et al. Mapping and Assessment of Ecosystems and their Services. An Analytical Framework for Ecosystem Assessments under Action 5 of the EU Biodiversity Strategy to 2020; Publications Office of the European Union: Luxembourg, 2013; p. 57.

13. Haines-Young, R.; Potschin, M. Common International Classification of Ecosystem Services (CICES): Consultation on Version 4, August-December 2012. EEA Framework Contract No EEA/IEA/09/003; Appendix; University of Nottingham: Nottingham, UK, 2013; p. 19.

14. Janhäll, S. Review on urban vegetation and particle air pollution-Deposition and dispersion. Atmos. Environ. 2015, 105, 130-137. [CrossRef]

15. Gunawardena, K.C.; Kershaw, T. Green and Blue-Space Significance to Urban Heat Island Mitigation; University of Bath: Bath, UK, 2016; p. 15.

16. Lin, Y.; Wang, Z.; Jim, C.Y.; Li, J.; Deng, J.; Liu, J. Water as an urban heat sink: Blue infrastructure alleviates urban heat island effect in mega-city agglomeration. J. Clean. Prod. 2020, 262, 121411. [CrossRef]

17. Haase, D.; Larondelle, N.; Andersson, E.; Artmann, M.; Borgström, S.; Breuste, J.; Gomez-Baggethun, E.; Gren, Å.; Hamstead, Z.; Hansen, R.; et al. A quantitative review of urban ecosystem service assessments: Concepts, models, and implementation. $A M B I O$ 2014, 43, 413-433. [CrossRef]

18. de Groot, R.; Wilson, M.; Boumans, R.A. Typology for the classification description and valuation of ecosystem functions, goods and services. Ecol. Econ. 2002, 41, 393-408. [CrossRef]

19. Hernández-Morcillo, M.; Plieninger, T.; Bieling, C. An empirical review of cultural ecosystem service indicators. Ecol. Indic. 2013, 29, 434-444. [CrossRef]

20. Monteiro, J. Ecosystem services from turfgrass landscapes. Urban For. Urban Green. 2017, 26, 151-157. [CrossRef]

21. Bieling, C. Cultural ecosystem services as revealed through short stories from residents of the Swabian Alb (Germany). Ecosyst. Serv. 2014, 8, 207-215. [CrossRef]

22. Giedych, R.; Maksymiuk, G. Specific features of parks and their impact on regulation and cultural ecosystem services provision in Warsaw, Poland. Sustainability 2017, 9, 792. [CrossRef]

23. Akpinar, A. How is quality of urban green spaces associated with physical activity and health? Urban For. Urban Green. 2016, 16, 76-83. [CrossRef]

24. Wang, Y.; de Groot, R.; Bakker, F.; Wörtche, H.; Leemans, R. Thermal comfort in urban green spaces: A survey on a Dutch university campus. Int. J. Biometeorol. 2017, 61, 87-107. [CrossRef]

25. van den Bosch, M. Natural Environments, Health, and Well-Being; Research Encyclopedia of Environmental Science: Oxford, UK, 2017; Available online: https:/ / oxfordre.com/environmentalscience/ (accessed on 19 July 2021).

26. Adinolfi, C.; Suárez-Cáceres, G.P.; Cariñanos, P. Relation between visitors' behaviour and characteristics of green spaces in the city of Granada, south-eastern Spain. Urban For. Urban Green. 2014, 13, 534-542. [CrossRef]

27. Cariñanos, P.; Casares-Porcel, M.; Guardia, C.; Aira, M.; Belmonte, J.; Boi, M.; Elvira-Rendueles, B.; De Linares, C.; FernándezRodríguez, S.; Maya-Manzano, J.; et al. Assessing allergenicity in urban parks: A nature-based solution to reduce the impact on public health. Environ. Res. 2017, 155, 219-227. [CrossRef] 
28. Ćwik, A.; Kasprzyk, I.; Wójcik, T.; Borycka, K.; Cariñanos, P. Attractiveness of urban parks for visitors versus their potential allergenic hazard: A case study in Rzeszów, Poland. Urban For. Urban Green. 2018, 35, 221-229. [CrossRef]

29. Kasprzyk, I.; Ćwik, A.; Kluska, K.; Wójcik, T.; Cariñanos, P. Allergenic pollen concentrations in the air of urban parks in relation to their vegetation. Urban For. Urban Green. 2019, 46, 126486. [CrossRef]

30. Kasprzyk, I.; Wójcik, T.; Cariñanos, P.; Borycka, K.; Ćwik, A. Evaluation of the allergenicity of various types of urban parks in a warm temperate climate zone. Aerobiologia 2019, 35, 57-71. [CrossRef]

31. Yang, Y.; Lu, Y.; Yang, H.; Yang, L.; Gou, Z. Impact of the quality and quantity of eye-level greenery on park usage. Urban For. Urban Green. 2021, 60, 127061. [CrossRef]

32. Cariñanos, P.; Adinolfi, C.; Díaz de la Guardia, C.; De Linares, C.; Casares-Porcel, M. Characterization of Allergen Emission Sources in Urban Areas. J. Environ. Qual. 2016, 45, 244-252. [CrossRef]

33. Kasprzyk, I.; Grinn-Gofron, A.; Ćwik, A.; Kluska, K.; Cariñanos, P.; Wójcik, T. Allergenic fungal spores in the air of urban parks. Aerobiologia 2021, 37, 39-51. [CrossRef]

34. Palliwoda, J.; Priess, J.A. What do people value in urban green? Linking characteristics of urban green spaces to users' perceptions of nature benefits, disturbances, and disservices. Ecol. Soc. 2021, 26, 28. [CrossRef]

35. Lyytimäki, J.; Petersen, L.K.; Normander, B.; Bezák, P. Nature as a nuisance? Ecosystem services and disservices to urban lifestyle. Environ. Sci. 2008, 5, 161-172. [CrossRef]

36. Vogt, J.S.; Hofmann, M.; Tharang, A.; Dettmann, S.; Gerstenberg, T.; Schmidt, C.; Gebauer, H.; Van de Riet, K.; Berger, U.; Roloff, A. Citree: A database supporting tree selection for urban areas in temperate climate. Landsc. Urban Plan. 2017, 157, 14-25. [CrossRef]

37. Mrđan, S.; Ljubojević, M.; Orlović, S.; Čukanović, J.; Dulić, J. Poisonous and allergenic plant species in preschool's and primary school's yards in the city of Novi Sad. Urban For. Urban Green. 2017, 25, 112-119. [CrossRef]

38. de Groot, R.S.; Alkemade, R.; Braat, L.; Hein, L.; Willemen, L. Challenges in integrating the concept of ecosystem services and values in landscape planning, management and decision making. Ecol. Complex. 2010, 7, 260-272. [CrossRef]

39. GUS. Statistics Poland. Available online: Stat.gov.pl (accessed on 24 March 2021).

40. TuTiempo Global Climate Data. Climate Rzeszow-Jasionka-Climate Data (125800). Available online: http://tutiempo.net (accessed on 18 February 2021).

41. Nieróbca, A.; Kozyra, J.; Mizak, K.; Wróblewska, E. Zmiana długości okresu wegetacyjnego w Polsce. Water Environ. Rural. Areas 2013, 13, 81-94.

42. AGROMETEO IMGW-BIP. Agrometeo—Pokaz. Dane Historyczne. Available online: https://agrometeo.imgw.pl/danehistoryczne/ (accessed on 18 February 2021).

43. ROSIR. Data of Rzeszów Sports and Recreation Center. Rzeszów, Poland, 2021; Unpublished.

44. Wikipedia 2021. Rzeszowska Fontanna Mulimedialna. Available online: https://pl.wikipedia.org/wiki/Rzeszowska_Fontanna_ Multimedialna (accessed on 18 February 2021).

45. Wójcik, T.; Ziaja, M.; Makuch, I.; Ćwik, A.; Kotańska, M. Szata roślinna rezerwatu "Lisia Góra” w Rzeszowie [Vegetation of the Lisia Góra Reserve in Rzeszów]. Fragm. Florist. Geobot. Pol. 2018, 25, 21-43.

46. Ziaja, M.; Wójcik, T. Changes in vascular flora of the Rzeszów Reservoir (SE Poland) after 20 years. Pol. J. Environ. Stud. 2015, 24, 1-11. [CrossRef]

47. Tokarska-Guzik, B.; Dajdok, Z.; Maria, Z.; Zając, A.; Urbisz, A.; Danielewicz, W.; Hołdyński, C. Rośliny Obcego Pochodzenia w Polsce ze Szczególnym Uwzględnieniem Gatunków Inwazyjnych-Alien Plants in Poland with Particular Reference to Invasive Species; Generalna Dyrekcja Ochrony Środowiska: Warsaw, Poland, 2012; p. 197.

48. Matuszkiewicz, W. A Guide to Identification of Plant Communities of Poland. Vademecum Geobotanicum; Wydawnictwo Naukowe PWN: Warsaw, Poland, 2001; p. 537.

49. Klotz, S.; Kühn, I.; Durka, W. BIOLFLOR: Eine Datenbank mit Biologisch-Ökologischen Merkmalen zur Flora von Deutschland; Schriftenreihe für Vegetationskunde; Bundesamt für Naturschutz: Bonn, Germany, 2002.

50. Sádlo, J.; Chytry, M.; Pergl, J.; Pyšek, P. Plant dispersal strategies: A new classification based on multiple dispersal modes of individual species. Preslia 2018, 90, 22. [CrossRef]

51. Łuczaj, Ł. Dzikie rośliny jadalne. Przewodnik surviavlowy [Wild Edible Plants of Poland]; Chemigrafia: Krosno, Poland, $2002 ;$ p. 236.

52. Oddo, L.; Piana, L.; Bogdanov, S.; Bentabol, A.; Gotsiou, P.; Kerkvliet, J.; Martin, P.; Morlot, M.; Valbuena, A.; Ruoff, K.; et al. Botanical species giving unifloral honey in Europe. Apidologie 2004, 35, 82-93. [CrossRef]

53. Kołtowski, Z. Wielki Atlas Roślin Miododajnych; Przedsiębiorstwo Wydawnicze Rzeczpospolita, S.A.: Warsaw, Poland, $2006 ;$ p. 328.

54. Pogorzelec, M. Atlas Roślin Miododajnych; Wydawnictwo Dragon: Bielsko-Biała, Poland, 2019; p. 448.

55. Mirek, Z.; Piękoś-Mirkowa, H.; Zając, A.; Zając, M. Flowering plants and pteridophytes of Poland. A checklist. In Biodiversity of Poland; Mirek, Z., Ed.; W. Szafer Institute of Botany, Polish Academy of Sciences: Kraków, Poland, 2002; p. 442.

56. Snowarski, M. Atlas of Vascular Plants of Poland. Available online: http://www.atlas-roslin.pl/index.html (accessed on 21 April 2021).

57. Piotrowska-Weryszko, K.; Weryszko-Chmielewska, E. The airborne pollen calendar for Lublin, central-eastern Poland. Ann. Agric. Environ. Med. 2014, 1, 541-545. [CrossRef] [PubMed]

58. Wójcik, T.; Makuch, I.; Ćwik, A.; Ziaja, M. Anthropogenic changes in selected elements of the natural environment in the Lisia Góra forest nature reserve in Rzeszów. Sylwan 2020, 164, 246-253. 
59. Wuijts, S.; Friederichs, L.; Hin, J.A.; Schets, F.M.; Van Rijswick, H.F.M.W.; Driessen, P.P.J. Governance conditions to overcome the challenges of realizing safe urban bathing water sites. Int. J. Water Resour. Dev. 2020, 1-25. [CrossRef]

60. Pouso, S.; Borja, Á.; Fleming, L.E.; Gómez-Baggethun, E.; White, M.P.; Uyarra, M.C. Contact with blue-green spaces during the COVID-19 pandemic lockdown beneficial for mental health. Sci. Total. Environ. 2021, 756, 143984. [CrossRef]

61. Nutsford, D.; Pearson, A.L.; Kingham, S.; Reitsma, F. Residential exposure to visible blue space (but not green space) associated with lower psychological distress in a capital city. Health Place 2016, 39, 70-78. [CrossRef]

62. D'Amato, G.; Spieksma, F.T.M. Allergenic pollen in Europe. Grana 1991, 30, 67-70. [CrossRef]

63. Hirons, A.D.; Sjöman, H. Tree Species Selection for Green Infrastructure: A Guide for Specifiers. Issue 1.3; Trees E Design Action Group: 2019. Available online: hirons-and-sjoman-2019-tree-species-selection-for-green-infrastructure-v13.pdf(csla-aapc.ca) (accessed on 21 April 2021).

64. Hayden, L.; Cadenasso, M.L.; Haver, D.; Oki, L.R. Residential landscape aesthetics and water conservation best management practices: Homeowner perceptions and preferences. Landsc. Urban Plan. 2015, 144, 1-9. [CrossRef]

65. Ignatieva, M.; Haase, D.; Dushkova, D.; Haase, A. Lawns in Cities: From a Globalised Urban Green SPACE phenomenon to Sustainable Nature-Based Solutions. Land 2020, 9, 73. [CrossRef]

66. Camacho-Cervantes, M.; Schondube, J.E.; Castillo, A.; MacGregor-Fors, I. How do people perceive urban trees? Assessing likes and dislikes in relation to the trees of city. Urban Ecosyst. 2014, 17, 761-773. [CrossRef]

67. Armentia, A.; Lombardero, M.; Callejo, A.; Barber, D.; Martin-Gil, F.J.; Martín-Santos, J.; Vega, J.; Arranz, M. Is Lolium pollen from an urban environment more allergenic than rural pollen? Allergol. Immunopathol. 2002, 30, 218-224. [CrossRef]

68. Twaroch, T.; Curin, M.; Valenta, R.; Swoboda, I. Mold allergens in respiratory allergy: From structure to therapy. Allergy asthma Immunol. Res. 2014, 7, 205-220. [CrossRef] [PubMed]

69. Palliwoda, J.; Kowarik, I.; von der Lippe, M. Human-biodiversity interactions in urban parks: The species level matters. Landsc. Urban Plan. 2017, 157, 394-406. [CrossRef]

70. Dylewski, Ł.; Maćkowiak, Ł.; Banaszak-Cibiecka, B. Are all urban green spaces a favourable habitat for pollinator communities? Bees, butterflies and hoverflies in different urban green areas. Ecol. Entomol. 2019, 44, 678-689. [CrossRef]

71. Krzymowska-Kostrowicka, A. Geoekologia Turystyki i Wypoczynku; Wydawnictwo Naukowe PWN: Warsaw, Poland, 1999 ; p. 239.

72. Calfapietra, C.; Fares, S.; Manes, F.; Morani, A.; Sgrigna, G.; Loreto, F. Role of Biogenic Volatile Organic Compounds (BVOC) emitted by urban trees on ozone concentration in cities: A review. Environ. Pollut. 2013, 183, 71-80. [CrossRef] [PubMed]

73. Jorgensen, A.; Anthopoulou, A. Enjoyment and fear in urban woodlands-Does age make a difference? Urban For. Urban Green. 2007, 6, 267-278. [CrossRef]

74. Amani-Beni, M.; Zhang, B.; Xie, G.-D.; Xu, J. Impact of urban park's tree, grass and waterbody on microclimate in hot summer days: A case study of Olympic Park in Beijing, China. Urban For. Urban Green. 2018, 32, 1-6. [CrossRef]

75. Dudek, T.; Kasprzyk, I.; Dulska-Jeż, A. Forest as a place for recreation but also the source of allergenic plant pollen: To come or avoid? Eur. J. For. Res. 2018, 137, 849-862. [CrossRef]

76. de Weger, L.A.; Pashley, C.H.; Šikoparija, B.; Skjøth, C.A.; Kasprzyk, I.; Grewling, Ł.; Thibaudon, M.; Magyar, D.; Smith, M. The long distance transport of airborne Ambrosia pollen to the UK and the Netherlands from Central and south Europe. Int. J. Biometeorol. 2016, 60, 1829-1839. [CrossRef]

77. Kawa, P. Ptaki zbiornika retencyjnego w Rzeszowie i terenów przyległych w latach 1982-2003. Ptaki Podkarpacia 2004, 10, 25-52. (In Polish)

78. Kukuła, K.; Bylak, A. Expansion of water chestnut in a small dam reservoir: From pioneering colony to dense floating mat. Period. Biol. 2017, 119, 137-140. [CrossRef]

79. Dunn, R. Global mapping of ecosystem disservices: The unspoken reality that nature sometimes kills us. Biotropica 2010, 42, 555-557. [CrossRef]

80. Bjerke, T.; Østdahl, T.; Thrane, C.; Strumse, E. Vegetation density of urban parks and perceived appropriateness for recreation. Urban For. Urban Green. 2006, 5, 35-44. [CrossRef]

81. Puc, M.; Kasprzyk, I. The patterns of Corylus and Alnus pollen seasons and pollination periods in two Polish cities located in different climatic regions. Aerobiologia 2013, 29, 495-511. [CrossRef] 